\title{
シアキーと接合幅をもつ PCa 構造接合部のせん断挙動と耐力評価に関する研究 STUDY ON SHEAR BEHAVIOR AND TRANSFER CAPACITY IN PRECAST CONCRETE CONNECTION WITH DIFFERENT WIDTHES AND SHEAR KEYS
}

\author{
斉煒*, 槙谷榮次**, 伊藤嘉則*** \\ Wei QI, Eiji MAKITANI and Yoshinori ITO
}

\begin{abstract}
The connection in precast concrete structure shares the important role for transfer of shear acting along the interfaces. The shear transfer capacity of connection is affected on shear elements such as joint concrete, connecting reinforcement and shear key. Also, it is greatly subjected to connection width formed between two precast units. However, there exist little the monographers which discussed on effect of the width in a precast concrete structure connection on shear transfer capacity. Herein, the direct shear test was performed for the purpose of investigating the contribution of connection width to shear transfer capacity. On the basis of test results obtained, the shear transfer capacity of connection was evaluated by using a compressive strut model. It was found that the theoretical results might estimate well the test ones.
\end{abstract}

Keywords : connection width, compressive strut mechanisms, slip displacement, shear keys 接合幅，圧縮ストラット機構，すべり変位，シアキー

1. 序

フルプレキャスト鉄筋コンクリート（以降， $\mathrm{PCa}$ 構造と呼ぶ）に おける接合部は，2 個の $\mathrm{PCa}$ ユニットが接合筋及びシアキーによっ て接合される。この $\mathrm{PCa}$ 構造接合部では, ユニット間はジョイント コンクリートによって充填され，接合幅が形成されることが実際の 施工で一般的に行っている。その接合幅の大きさは，施工性を優先 して決められることが多い。PCa 構造接合部におけるせん断伝達に ついては，多くの研究により，接合筋及びシアキーに関してのせん 断抵抗機構が明らかになりつつあり。しかし，その多くは，接合幅 を一定としたものであり，接合幅の違いが，せん断伝達能力に与え る影響について調べた研究は，皆無に近いと思われる。これに対し て著者らは, 既往の研究 5) でジョイントコンクリート及び接合筋か らなり,シアキーのないプレーンタイプの PCa 構造接合部の直接せ ん断実験を行った。それによるとせん断伝達能力は，2つの $\mathrm{PCa}$ ユ ニット間に存在する接合幅に大きな影響を受けることが明らかとな った。また，そのせん断力に対する評価式も提案し，実験結果に良 く対応することが検証された。

そこで本研究では，せん断抵抗要素として重要なシアキーを含め た PCa 構造接合部のせん断伝達能力として, 接合幅が与える影響に ついて調べることを目的とし，PCa 構造接合部の直接せん断実験を 行った。更に，得られた実験結果をもとにして，2つの接合面のシ
アキー間に形成される圧縮ストラットモデルを用いて，接合幅を考 慮に入れたせん断耐力に対する評価式を導いた。その結果, 評価式 は，実験結果を精度良く推定することが検証された。以下に，得ら れた研究成果を報告する。

\section{2. 実験概要}

\section{1 試験体}

本研究に用いた試験体は, 図 1 に示すように, 架構式及び壁式を 問わない, PCa 構造における鉛直接合部を応力伝達要素として局部 的に想定したものである。試験体は，中央部にモルタルと接合筋で $30 ， 60 ， 120 ， 160 ， 200 \mathrm{~mm}$ の幅を有する接合部を構成し，接合面に はシアキーを付設して, 2 個のニニットのPCa 部材で挟む形とした。 但し，接合部内には接合筋以外の鉄筋(補強筋)を施していない。ま た，接合幅を $0 \mathrm{~mm}$ とした $\mathrm{PCa}-\mathrm{RC}$ 造試験体との比較も行ってい る。なお，今回の実験で使用した接合筋は，せん断抵抗を単純化す るため，通し鉄筋（SD345）としている。また，接合笳径に対する定 着長さの影響をなくす為, 接合筋末端は定着ワッシャーと鉄筋ネジ で固定した。試験体の製作方法は，あらかじめ型枠を水平に設置し， 接合面型枠はシアキ一を付すために発泡スチロールを接着し，先に 接合筋を 2 ユニットの $\mathrm{PCa}$ 部に渡して配筋し，ユニット部は主筋 4-D16（SD785）とせん断補強筋 D13(SD785)@70mm で補強した。ま
* 関東学院大学大学院工学研究科建築学専攻 工修

** 関東学院大学工学部建築学科 教授.工博

*** 建材試験センター中央実験所構造グループ エ修
Graduate Student, Dept. of Architecture, Faculty of Engineering, Kanto-Gakuin, M. Eng,

Prof., Department of Architecture, Faculty of Engineering, Kanto-Gakuin University, Dr. Eng.

Japan Testing Center for Construction Material, M. Eng. 
た加力治具固定用に P C 鋼棒 $17 \phi$ を埋め込んだ後，PCa 部にコン クリートを打設した。養生脱型後は，中央接合部における型枠とし ての発泡スチロール材を撤去して，接合境界面には摩擦抵抗をなく すため表面にグリスを塗布して接合部にモルタルを打設した。製作 した試験体は合計 66 体とし, 変動要因は, 表 1 に示すように, 接 合幅, 接合筋径 (D10,D13,D16), 本数 $(2,3,4,5$ 本), シアキーの形 状及びシアキーの個数とした。シアキー形状は，図 2 に示すとおり シアキー幅高さ比とシアキー角度を変化させた 9 種類のシアキータ イプを接合境界面に配置した。ただし，シアキ一形状は，既往の研 究成果 1)を参考にして, シアキー染さに対する幅比を $2 \sim 8$ まで設 定し, 推定されるシアキーの破壊モードが起こり得る形状を適用し た。試験体における材料性状流 2 及び表 3 に示す。

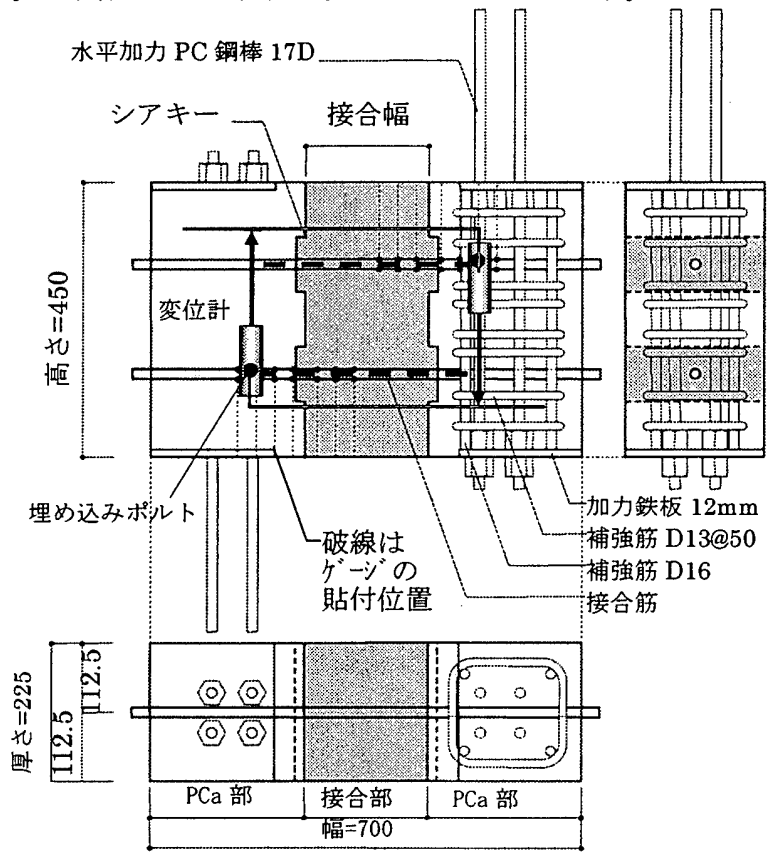

図 1 試験体及び計測方法

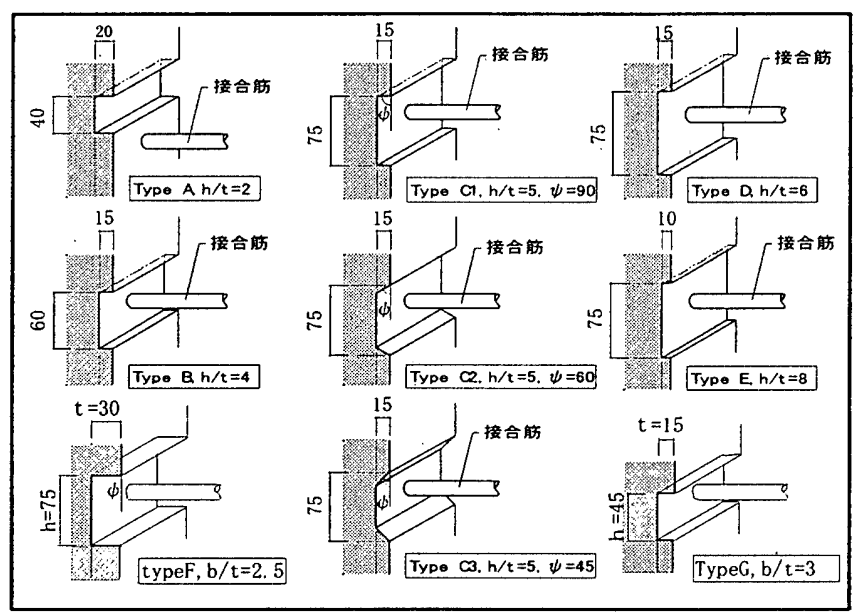

図 2 シアキー形状図

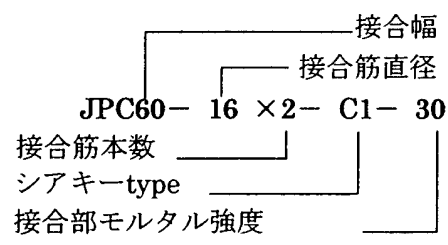

表 1 試験体一覧表

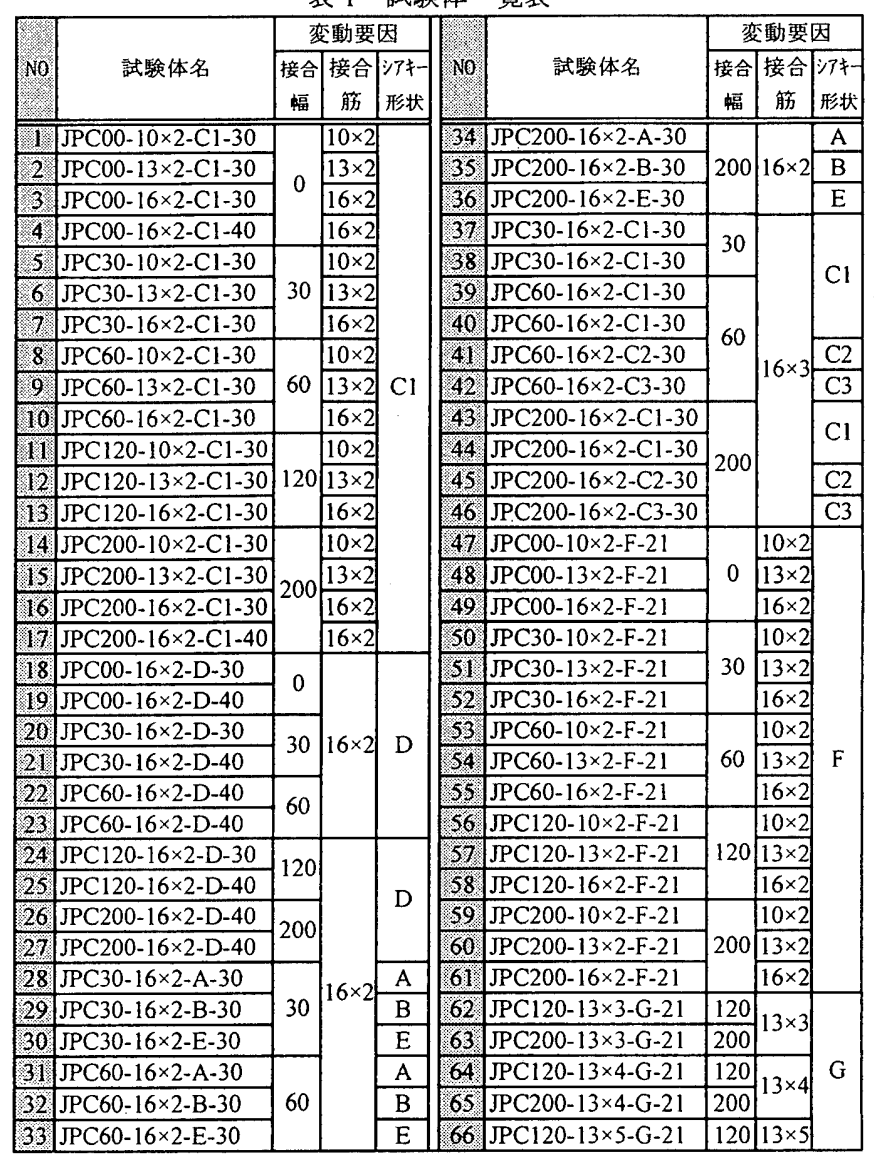

表2 コンクリート材料性状

\begin{tabular}{|c|c|c|c|c|c|c|}
\hline \multirow{2}{*}{$N_{0}^{*}$} & \multicolumn{3}{|c|}{$\mathrm{PCa}$ 部コンクリー } & \multicolumn{3}{c|}{ 接合部モルタル* } \\
\cline { 2 - 7 } & $\sigma_{\mathrm{B}}$ & $\mathrm{F}_{\mathrm{t}}$ & $\mathrm{Ec}$ & $\sigma_{\mathrm{Bj}}$ & $\mathrm{F}_{\mathrm{t}}$ & $\mathrm{Ec}$ \\
\cline { 2 - 7 } & $\mathrm{N} / \mathrm{mm}^{2}$ & $\mathrm{~N} / \mathrm{mm}^{2}$ & $\mathrm{kN} / \mathrm{mm}^{2}$ & $\mathrm{~N} / \mathrm{mm}^{2}$ & $\mathrm{~N} / \mathrm{mm}^{2}$ & $\mathrm{kN} / \mathrm{mm}^{2}$ \\
\hline $1 \sim 4$ & 31.9 & 2.6 & 22.1 & 40.1 & 3.7 & 22.0 \\
\hline $5 \sim 7$ & 32.0 & 2.6 & 28.2 & 53.0 & 4.4 & 22.2 \\
\hline $8 \sim 10$ & 31.3 & 2.7 & 24.9 & 59.0 & 4.7 & 22.6 \\
\hline $11 \sim 17$ & 32.3 & 2.3 & 24.7 & 57.2 & 3.3 & 22.0 \\
\hline $18 \sim 22$ & 28.2 & 2.1 & 23.3 & 38.0 & 2.4 & 23.3 \\
\hline $23 \sim 27$ & 27.8 & 2.4 & 23.2 & 42.7 & 2.3 & 23.7 \\
\hline $28 \sim 36$ & 34.2 & 2.2 & 21.7 & 35.1 & 2.7 & 22.5 \\
\hline $37 \sim 46$ & 34.5 & 2.2 & 20.8 & 35.0 & 2.3 & 21.4 \\
\hline $47 \approx 49$ & 24.4 & 2.4 & 22.1 & 32.8 & 2.6 & 22.0 \\
\hline $50 \sim 55$ & 26.0 & 2.2 & 28.2 & 41.5 & 2.6 & 22.2 \\
\hline $56 \sim 61$ & 25.2 & 2.3 & 24.9 & 37.5 & 2.0 & 22.6 \\
\hline $62 \sim 66$ & 24.2 & 2.2 & 24.7 & 41.0 & 2.2 & 22.0 \\
\hline
\end{tabular}

$\sigma_{\mathrm{B}}, \sigma_{\mathrm{Bj}}$ : 圧縮強度, $\mathrm{Ft}$ : 割裂強度, Ec:やング保数

*: 接合幅 $0 \mathrm{~mm}$ の試験体には, RC部コンクリート強度とした。

表3 鉄筋の機械的性質

\begin{tabular}{|c|c|c|c|c|}
\hline \multirow{2}{*}{ 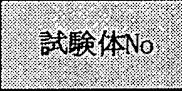 } & \multirow{2}{*}{ 種類 } & 降伏強度 & 引張強度. & やング係数 \\
\hline & & $\sigma_{y}\left(\mathrm{~N} / \mathrm{mm}^{2}\right)$ & $\sigma_{u}\left(\mathrm{~N} / \mathrm{mm}^{2}\right)$ & $\mathrm{Es}\left(\mathrm{kN} / \mathrm{mm}^{2}\right)$ \\
\hline \multirow{3}{*}{ No. 1 No. 17} & $\overline{\mathrm{D} 10}$ & 367 & 541 & 193 \\
\hline & D13 & 373 & 527 & 187 \\
\hline & D16 & 371 & 595 & 211 \\
\hline No. 18 No. 28 & D16 & 377 & 537 & 207 \\
\hline No. $28-N o .36$ & D16 & 390 & 596 & 191 \\
\hline No.37 -No.46 & D16 & 390 & 596 & 197 \\
\hline \multirow{3}{*}{ No. $47 \sim$ No. 66} & D10 & 455 & 607 & 192 \\
\hline & D13 & 388 & 538 & 191 \\
\hline & D16 & 403 & 619 & 204 \\
\hline
\end{tabular}


なお本論では，接合部内にモルタルを使用したが，実際には，接 合幅の大きさによって,コンクリートを使用するところもあり得る。 その場合，粗骨材のかみ合い作用による効果が発揮されるものと考 えられる。しかし，せん断耐力に与えるその影響は小さいと思われ る。また一軸圧縮強度で評価するので，どちらの材料を使用しても 同じとして扱った。

\section{2 加力方法と測定方法}

加力方法は，図 3 に示すように試験体を垂直に設置し，試験体の $P C a$ 部に埋め込んだ $P C$ 銅棒によって，水平方向から接合部の中心 線上に，押し引き用のオイルジャッキを用いてせん断力を与える S 型加力方式で行う。加力スケジュールは, Nol〜No34 及びNo47〜6 2 試験体は，変位制御により，相対すべり変位(以降，すべり変位と 呼ぶ) $\pm 0.5,1,2,4,6,8,10,12 \mathrm{~mm}$ の 8 サイクルに+15mm の押し切りを加 えた変位制御による正負交番繰り返し載荷とした(一部の試験体で は終局変形を+12mm まで制御した)。No.35〜No.46 及びNo.62〜No. 66 試験体は，一方向単調水平力を加えて，15 mm まで変位制御によ る載荷とした。

測定方法は，図 1 に示すように, $P C a$ 部に設置した高感度変位計 によって $P C a$ 部材間のすべり変位を測定し，相対すべり変位 $\delta_{s}$ と する。また，荷重は加力用のオイルジャッキに取り付けた $1 \mathrm{MN}$ 口 ードセルによって測定し，接合筋に貼付したワイヤーストレインゲ 一ジによって接合面近傍における接合筋各部のひずみを測定する。

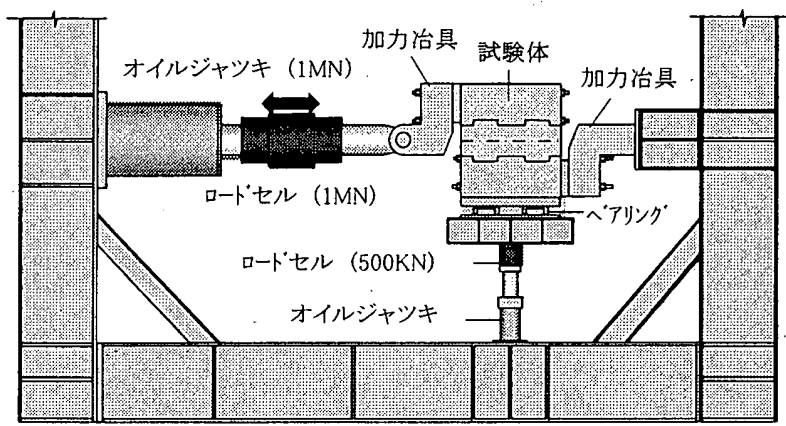

図 3 加力図

\section{3. 実験結果}

\section{1 ひび割れ及び破壊性状}

各試験体の破壊モードを表 4 に示した。ここで, 破壊モード $\mathrm{A} は$ シアキー隅角部から加力鉄板を結ぶ斜めひび割れによる破壊，破壊 モード B は 2 個のシアキー間のシアオフ破壊 6 ，破壊モード D は シアキー隅角部近傍 $\mathrm{PCa}$ 部の圧壊による破壊, 破壊モード $\mathrm{E}$ はシ アキー隅角部近傍接合部側のコンクリート圧壊による破壊, 破壊モ ード F は接合部斜めひび割れの進展による破壊。 $[\mathrm{AB}] ，[\mathrm{FD}]$ な どの 2 つの記号を含めたものは, 最初の記号は最大耐力時に観察し 得られた破壊モード，第 2 番の記号は最大耐力後に観察し得られた 破壊モードである。なお, 記号が 1 つのものは, 最大耐力時及び最 大耐力後の破壊モードが同じであったことを示す。代表的破壊モ一 ドを生じる試験体における接合部ひび割れ性状を図 4 に示した。試 験体接合部の界面にグリスを塗布しているため, 加力初期より接合 界面に初ひび割れが生じていた。但し，接合幅，シアキー形状によ． る変化は見受けられない。その後, 接合幅 $0 \mathrm{~mm}$ は, シアキー隅角

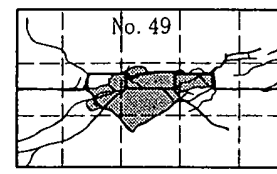

破壊モード $\mathrm{AB}$

(a) $\mathrm{JPC} 00 \cdot 16 \times 2 \cdot \mathrm{F}$

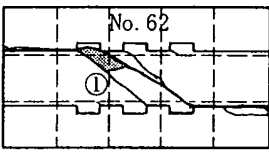

破壊モード FE

(d) $\mathrm{JPC} 120 \cdot 13 \times 3 \cdot \mathrm{G}$

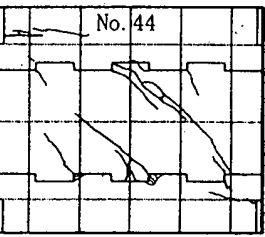

破壊モード F

JPC $200 \cdot 16 \times 3$

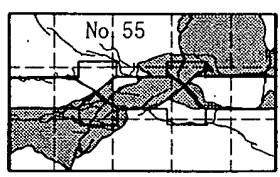

破壊モード FD
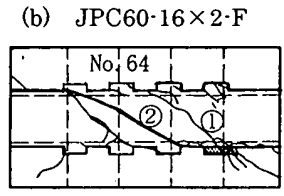

破壊モード FE

(e) $\mathrm{JPC} 120 \cdot 13 \times 4 \cdot \mathrm{G}$

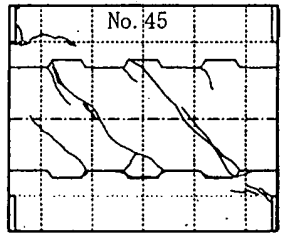

破壊モード F

$\mathrm{JPC} 200 \cdot 16 \times 3 \cdot \mathrm{C} 2$

図 4 各破壊モードとひび割れ性状

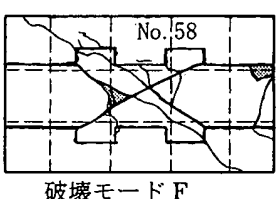

c) $\mathrm{JPC} 120 \cdot 16 \times 2 \cdot \mathrm{F}$

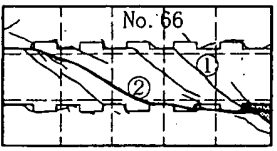

破壊モード F

(f) $\mathrm{JPC} 120 \cdot 13 \times 5 \cdot \mathrm{G}$
部から加力鉄板を結ぶ斜めひび割れ(図 4(a))，接合幅 30 と $60 \mathrm{~mm}$ では，1組のシアキー隅角部を結ぶ斜めひび割れ(図 4(b))，接合幅 $120 \mathrm{~mm}$ は, シアキー2 組の隅角部を結ぶ斜めひび割れ(図 $4(\mathrm{c}$ ))を 生じた。シアキ一の個数の違いによる影響は, 図 4 のd, e, fに示 すように, シアキーEタイプの試験体には，初ひび割れ後にシアキ 一から約 45 度の斜めひび割れが発生した。その後, 荷重の増大に よって，隣接 2 個のシアキーの隅角部を結ぶひび割れ(1)を生じた。 最終破壊性状は, 各試験体ともに端部のシアキーの端部から 3 つ目 のシアキーを結ぶ斜めひび割れ(2)の急激な進展により滑り面が形成 され，荷重が急激に劣化し，終局に至っている。また，シアキー形 状の違いによる影響は図 4 の $\mathrm{g}, \mathrm{h}, \mathrm{n}$ に示すように, 最大耐力まで 殆んど見られない。但し，すべり変位の增大により，角度 $\phi=90^{\circ}$ のシアキ一部分の支圧破壊によるコンクリートの剥落が激しくなる のに対して, シアキーtypeC2,C3( $\left.\phi=60,45^{\circ}\right)$ の方が斜めに沿って 滑りが卓越したことが見受けられた。

以上の破壊性状について検証すると，既往の論文》によれば，接 合幅の影響を考慮してない試験体に対して; シアキーの幅/高さ比 $\mathrm{h}$ $/ \mathrm{t}=5$ より小さい形状ではシアキーのせん断破壊， $\mathrm{h} / \mathrm{t}=5$ 以上であれ ばシアキ一隅角部の支圧破壊という破壊モードが指摘されているが， しかし，本研究のように接合幅がある場合には殆どの場合がシアキ 一内の斜めひび割れ(破壊モードF) で最大耐力が生し，脆性的な破 壊を生じることが判った。この斜めひび割れは，斜張力破壊に似た 挙動を示していた。しかし，実際にはシアキー内（接合幅の違いに より 1 組又は 2 組) の圧縮域を, 数本の斜めひび割れの進展により, 最大耐力が得られるという破壊性状を示していた。このような場合， ひび割れが生じたジョイントコンクリート内では，圧縮主応力方向 （ひび割れ方向）に，なお内力として抵抗し，圧縮力は，シアキ一 内の圧縮域を，直線的に流れていき，ストラット構造に近い耐荷機 構を形成していると考えられる。しかし；接合部分には，せん断補 強筋などの補強鉄筋がないため，接合部モルタルは，周辺の拘束効 果を受けず圧縮ストラットに相当するコンクリートが一軸圧縮強度 に達した瞬間に破壊を引き起こしたものと考えられる。従って，接 合幅を有する試験体に対して，シアキーがせん断(支圧)破壊耐力に 
達する前に, シアキー内の斜めひび割れが進展し，接合部内に形成 された圧緶ストラットがコンクリート生縮強度に達して, 最大耐力 に至ると考えられる。

\section{2 履歷性状及び強度性状}

シアキーを有する試験体に対して，図 5 に示すように，加力初期 は殆どすべり変位は生じて抢らず，ほほ荷重軸と平行に耐力上昇を 続けており，多くの試験体で初ひび割れによりすべり変位を生じて いる。また，接合部内に斜めひび割れ破壊が生じると急激に耐力が 低下寸ると共に，変位の増大と接合筋が降伏を示した。その後，変 位の增加に伴いながら緩やかに耐力の低下を続け，すべり変位 $15 \mathrm{~mm}$ 時にはシアキーのない試験体 5.10)とほぼ同等の耐力となった (図 5 に破線で示す)。最大耐力レベルでシアキーによる変位の拘束, せん断伝達が支配的であることが判り，どの試験体においても脆性 的な破壊を示した。

各試験体に対して, 最大荷重時 $\mathrm{Q}_{\max }$ の耐力及び変位を表 4 に示す。 最大耐力時に見られた破壊モ一ドは，接合幅 $0 \mathrm{~mm}$ を除いて，概ね斜 めひび割れ(ひび割れモードF)による破壊であった。しかし，最大酎 力時におけるすべり変位は $\delta \mathrm{s}=0.10 \sim 3.2 \mathrm{~mm}$ とその範囲がやや大き い。更に，接合幅及びシアキー形状などの影響因子と明確な関係は 見られなかった。ただし平均値的には，0.68 $\mathrm{mm}$ であり，微小変形で 最大耐力が得られることが分かる。

また，既往の研究によると，シアキーの高さ幅比 $(\mathrm{h} / \mathrm{t})$ が 5 を境 に破壊モードが決まるとされている。そこでシアキー形状による比 較として図 6 に最大せん断力とシアキー幅高さ比の関係を示す。図 6 より, h/t が 5 以下の試験体 typeA,B について，せん断面積に着目 して見ると，せん断面積に比例した最大せん断応力が得られていな い。更に, h/t が 5 以上の typeC1,D,E の試験体のうち, 接合幅 $60 \mathrm{~mm}$ の試験体を見ると, TypeD の鉛直投影面積(As)は TypeEより大きい が，最大せん断态力は, Type Eの方が高い傾向を示していた。また 全体的な傾向としても，最大せん断応力度とせん断面積並びにシア キーの支圧面積とは，明確な関倸が見受けられなかった。

一方：シアキー形状の違いが，せん断力に与える影響を調べるた めに, シアキー側面角度に違いのある typeC1，C2，C3 試験体において は，図 7 に示すように，シアキー側面角度が 45 度の typeC3 試験体 が相対的に高い耐力を示した。また，シアキ高さの違いによる影響 を調べるために, 圾験体 No. 1〜 No. 17 によるシアキー高さ $15 \mathrm{~mm}$ (幅/ /高さ比が 75/15)の試験体と試験体 No. 47〜No.61 のシアキー高さ
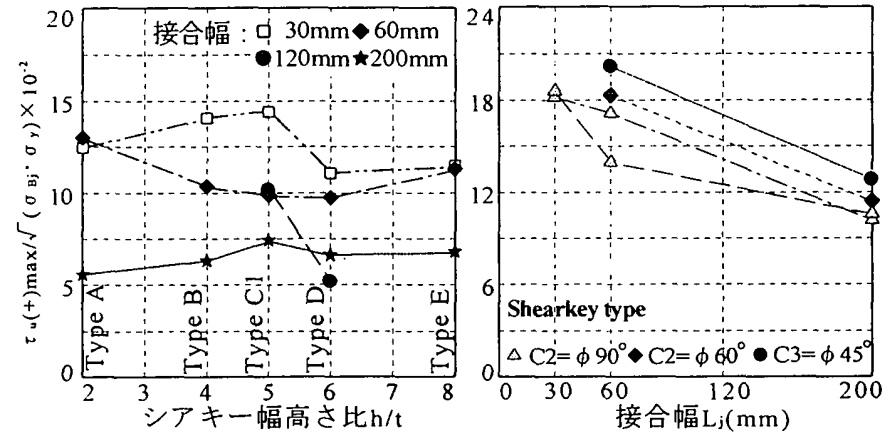

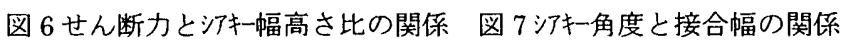

$30 \mathrm{~mm}$ (媣さ幅比が 30/75) 試験体の最大せん断応力を図 8 にプロット した。変動要因がシアキーの染さのみである場合, シアキーの深さ が大きい方 $(15 \mathrm{~mm} \Rightarrow 30 \mathrm{~mm})$ が, 最大せん断応力度は増大寸る。これは,

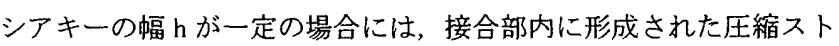
ラットの面積がシアキー支圧面積 (シアキーの媣さ)に強く依存して いるためと考えられる。

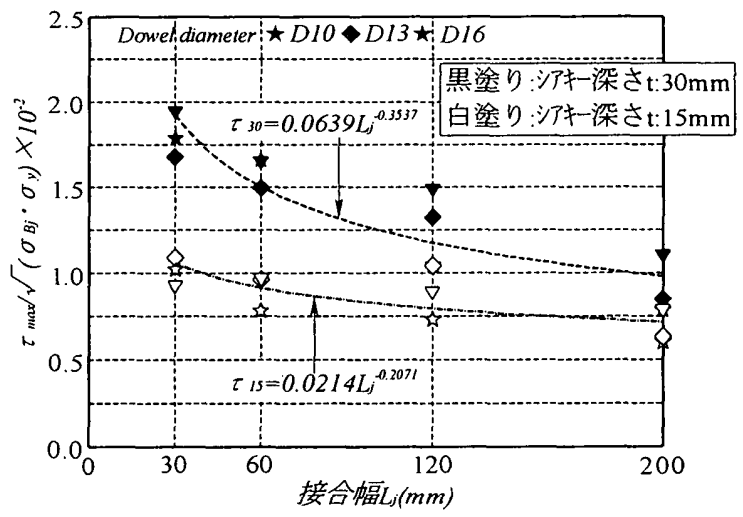

図 8 シアキーの高さによるせん断耐力の比較

また，実験結果一覧表 4 を見ると，試験体における接合部コンク リート(モルタル)强度 $\sigma_{\mathrm{Bj}}$, 鉄筋強度 $\sigma_{\mathrm{y}}$, シアキーの形状 $(\mathrm{h} / \mathrm{t})$ 及 び接合筋の断面積(as)が違うので, 比較を容易にする為に,ここでは, 実験から得られたせん断耐力を無次元化したもの $\tau_{\mathrm{d}} / \sigma_{\mathrm{Bj}} \cdot \lambda$ と接合 筋係数 $\mathrm{q}_{d} \lambda$ との関倸を図 9 にプロットした。ここで, $\tau \mathrm{u}=\mathrm{Q}_{\max } / \mathrm{A}$, $\mathrm{q}_{\mathrm{c}}=\mathrm{a}_{\mathrm{s}} \cdot \sigma_{\mathrm{y}} / \mathrm{A} \cdot \sigma_{\mathrm{Bj}}$, シアキーの断面積比 $\lambda=\mathrm{As} / \mathrm{A}, \mathrm{A}$ は試験体の全せ ん断面積, As はシアキーのせん断面積である。なお，ここでの検証 は, シアキーを有するものの接合幅の影響を考虑しない既往の終局

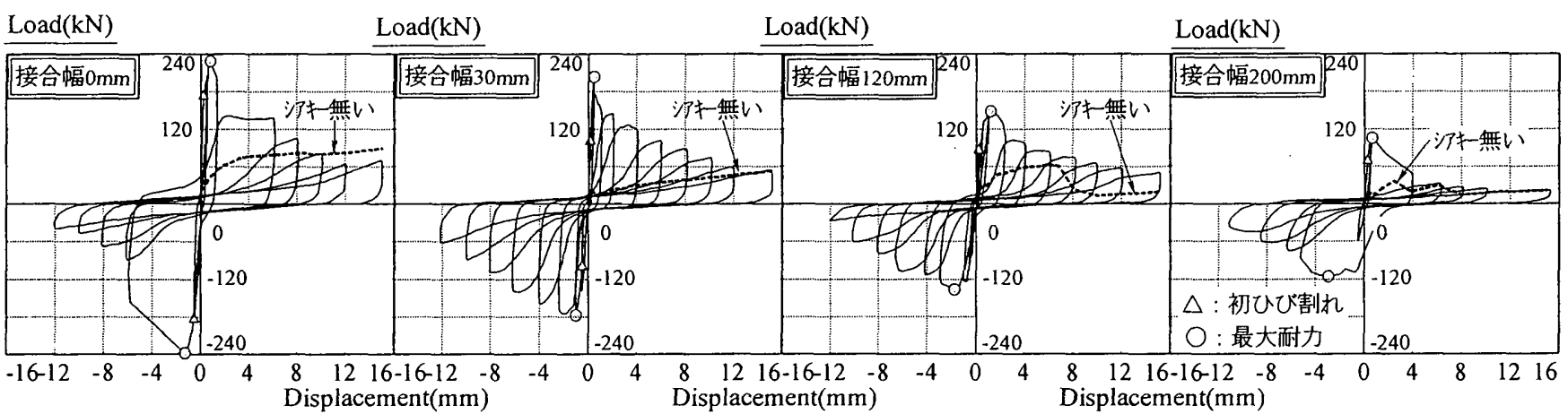

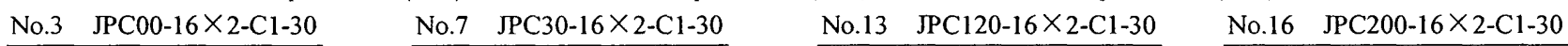

図 5 試験体における代表的な荷重·変位曲線 


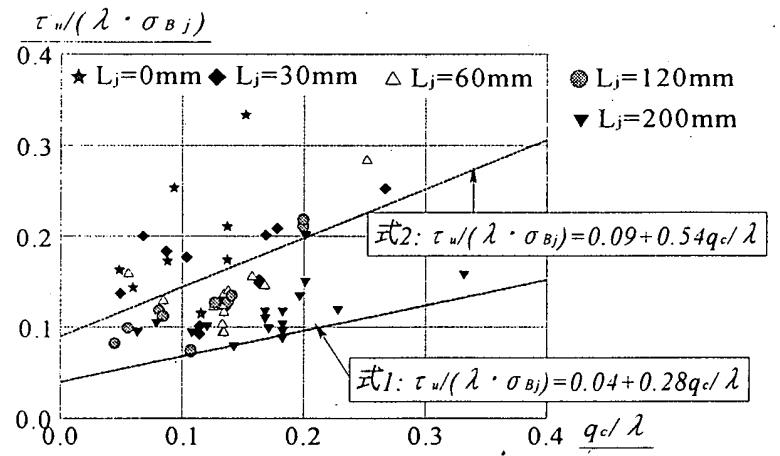

図 9 接合筋倸数一せん断力の関保

せん断強度式 ${ }^{8)}$ と奏験結果との比較を行うため, 無次元化に用いた ファクターは, 既往のせん断強度式に用いられている因数をもとに 採用した。これより，プロットされたせん断耐力に対する実験值は， 接合筋係数の増加と共にあるばらうつきを持って増加する傾向が見ら れる。一方，ダウエル効果を無視した望月式 ${ }^{16)}$ と同じようにせん断 抵抗はシアキーの直接せん断抵抗と接合筋のせん断摩摖抵抗が累加 できると考えて，実験結果から，下限近似線(式 1)を求めた。しかし 望月式(式 2)と比較すると, 下限近似線(式 1)は, 望月式の半分ぐら いしかない。これは接合幅による耐力低下に起因しているためと推 測される。

実験結果と建築学会式 ${ }^{2)}$ 及び望月・樃谷・永坂式 16$)$ の比較を図 10 に示した。接合幅の影響を考虑していない既往の接合部せん断耐力 式(建筑学会式，望月・椳谷·永坂式)は接合幅の増大につれ，いずれ も過大評価になっていることが判る。また, 接合幅 $0 \mathrm{~mm} の$ 試験体 に対して，建築学会式及び望月式の比較は，平均的に見ると， $Q_{\text {实弱 }}$ 值 $/ Q_{\text {学会 }}=0.85, Q_{\text {英弱值 }} / Q_{\text {望月式 }}=0.88$ となり, やや低く $20 \%$ 以内に収 まることが判った。

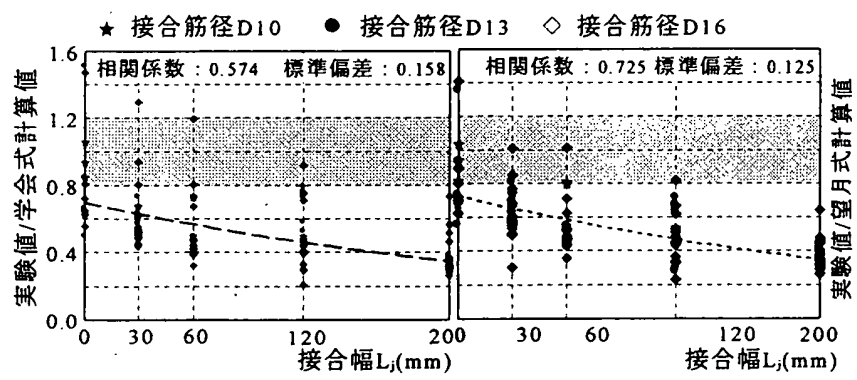

図 10 接合幅一学会式及び望月式との比較

\section{3 接合筋における応力状況}

接合筋の裹および表に貼り付けたゲージによって鉄筋のひずみ変 化を測定した。ここで，各測定点における表裏ひずみの和の平均を 軸力によるひずみ，差の $1 / 2$ を曲げによるひずみとして弾性範囲に おいて換算を行った。接合筋に作用する軸力と曲げモーメントは下 式に示した。( $d r$ は，接合筋の直径 $)$

$$
\begin{aligned}
& M=\frac{\left(\sigma_{\text {品 }}-\sigma_{\text {舞 }}\right)}{2}: \frac{\pi \cdot d r^{3}}{32} \quad(\text { 弹性曲げモーメント) } \\
& N=\frac{\left(\sigma_{\text {数 }}+\sigma_{\text {照 }}\right)}{2} \cdot \frac{\pi \cdot d r^{2}}{4} \quad \text { (弾性軸方向力) }
\end{aligned}
$$

式(1)及び式(2)を用いて計算された結果によると，各試験体では， 加力初期より全体に引張力が発生しており，初ひび割れと共に曲げ
モーメントが発生する。最大耐力時には，概ね接合筋降伏軸力の 40\% 90\%程度の引張力が発生しており，接合幅が小さくなるにつ れて引張力は大きくなっている。ここにシアキーを有する試験体と シアキーの無い試験体 ${ }^{5}$ (10)の接合筋における最大モーメント部の曲 げモーメント $M$ ，軸方向力 $N$ の関倸を図 11 に示した。シアキーの無 い試験体は曲げモーメントが大きく発現したことに対して，シアキ 一を有する試験体は最大耐力までほほ直線的に増加し，大きな引張 軸力を生じているが，曲げモーメントは相対的に小さい。最大耐力 以降は接合筋断面に働く曲げ抵抗の方が支配的である。これは，シ アキーの有無によって，最大耐カレベルで接合筋の引っ張りによる せん断摩擦抵抗と曲げモーメントによるダウエル抵抗の卓越性の違 いに起因していると考えられる。なお，ここで云うせん断摩擦抵抗 とダウエル抵抗とは，以下のように定義する。接合界面にすべり変 形を生じた時，接合筋には塑性ヒンジが形成される。このヒンジ間 における接合筋直下のコンクリートは, 支圧による抵抗メカニズム を示す。この抵抗メ゙カニズムを曲げモーメントによるダウェル抵抗 とする。更にすべり変形が進むと接合筋には，局部的なくびれ変形 が生じ，曲げモーメントによるせん断力以外に接合筋には，降伏引 張力が生じる。この引張力の反力によって接合界面の垂直方向には, コンクリートによる圧縮応力が作用する。この抵抗メカニズムを， 接合筋の引張によるせん断摩擦抵抗とする。

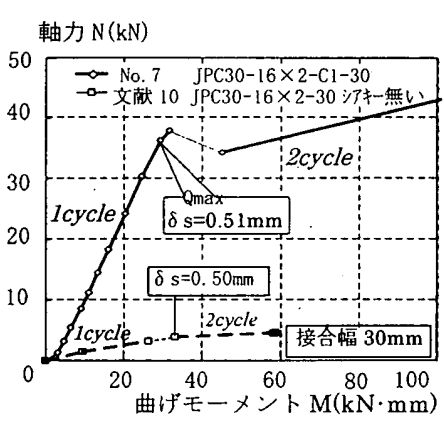

軸力 $N(\mathrm{kN})$

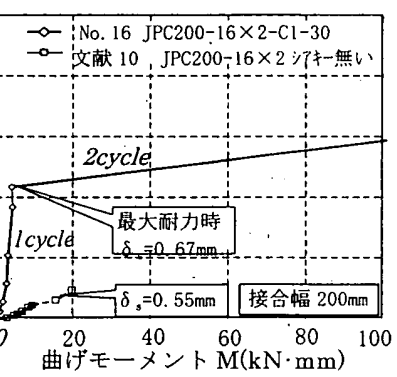

図 11 接合筋における曲げモーメント軸力の関係

また, 各試験体の最大耐カレベルにおける接合筋の弾性域レベル の引張軸力 $\mathrm{N}_{\text {max }}$ 及び接合筋の弾性域レ゙ベル段階最大曲げモーメント $M_{\text {max }}$ に対して, 接合筋の降伏引張力 $N y\left(=\sigma_{y} \cdot \pi d r^{2} / 4\right)$ 及び降伏曲 げモーメント $M y\left(=\sigma_{y} \cdot \pi d_{r}^{3} / 32\right)$ との比を求めると, 接合筋の引張 軸力低減係数 $\gamma_{\mathrm{s}}\left(\gamma_{\mathrm{s}}=N_{\max } / N_{y}\right)$ と曲げモーメント低減係数 $\gamma_{\mathrm{m}}\left(=M_{\max }\right.$ $\left.M_{y}\right)$ が得られる。その各低減倸数を接合幅との関倸で図 12 に示す。

この図によると, 最大耐力時において接合筋の引張（平均 $N_{\text {max }} / N_{y}$ $y=0.612$ ) によるせん断摩擦は, 接合筋の曲げモーメント(平均 $M_{\text {max }}$

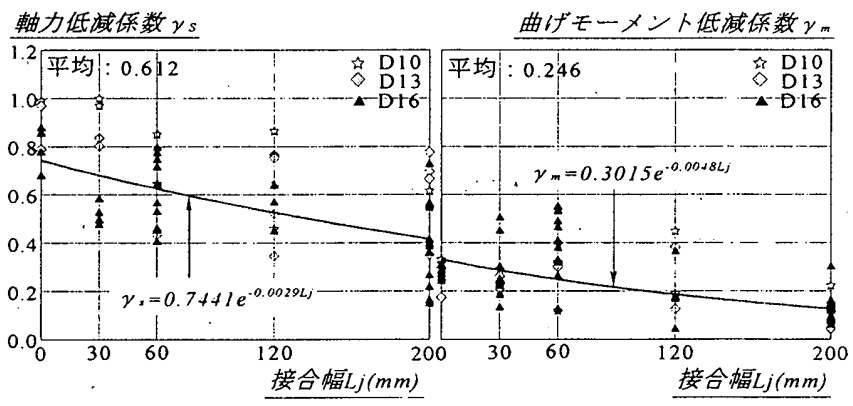

図 12 . 接合筋の各低減係数一接合幅の関係 
/ $M_{y}=0.246$ )によるダウエル抵抗より大きく支配されていることが 判る。また, 接合幅が大きくなるにつれて, 軸力低減倸数 $\gamma_{s}$ が低下 している傾向が見られる。これは，接合幅の違いが接合筋のせん断 摩擦抵抗に大きく影響を与えているためと考えられる。

\section{4. せん断抵抗機構の考察}

\section{1 全せん断抵抗機構}

シアキーを持つ試験体に対して, 接合部のせん断抵抗要素として, (1)シアキーのせん断及び支圧抵抗 $Q_{C l}$ ，(2) 接合部ジョイントコン クリートのせん断抵抗 $Q_{C 2}$ ，（3）接合筋によるせん断摩擦抵抗 $Q_{f}$, (4)接合筋のダウエル抵抗 $Q_{d}$ を考える（接合面にグリスを塗布した ため，コンクリートの付着摩擦抵抗を無視した)。図 13 には各せん 断抵抗提案モデルを示す。これらの抵抗要素において，シアキーの せん断抵抗及び接合部コンクリートのせん断抵抗が微小変位で耐力 を発揮する抵抗特性をもつ。一方，鉄筋のダウエルせん断抵抗は， すべり変位がある程度以上になると, 耐力を十分に発揮する抵抗特 性を示す。従って, 各せん断抵抗は単純に累加できないと考えられ る。シアキーを有する試験体に対して，剛性が大きいシアキーの拘 束によって，試験体は微小変形でせん断力が最大值に至り，脆性的 なせん断破壊性状を示す。従って，本論文では，試験体がある程度 のすべりを生じる時(あるいは最大耐力以後)のせん断耐力 Qu1 を評 価することを省略して，主に微小変形で至るせん断力の最大值をせ 儿断抵抗 $Q_{\mathrm{u}}$ として評価する。

なお，補強筋を施した場合，鉄筋による拘束効果などの付加的な 効果が生じることが推測される。これに対して，本論で得られる結 果は，下限值を与えるものとして考えられる。従って，補強筋を使 用した場合については，その付加的な効果を除けば，本論の試験体 条件でも十分検証するに值するものと思われる。

接合幅をもつ圾験体のひび割れ性状によっると,シアキーがせん断( 支圧)破壊を生じる前に, ジョイントコンクリートが先に破壊するこ とが認められた。これより, シアキーを有する接合部コンクリート のせん断抵抗 $\left(Q_{C}\right)$ は, シアキーのせん断(支圧)抵抗 $\left(Q_{C l}\right)$ とジョイン トコンクリートのせん断抵抗 $\left(Q_{C 2}\right)$ の内, 小さい方の值によって決め られる。また，接合筋のせん断摩擦抵抗 $(Q)$ ) とダウエル抵抗 $\left(Q_{d}\right)$ に対 して，鉄筋のひずみ分布から求めた接合筋の軸力及び曲げモーメン トの低減係数 $\gamma_{\mathrm{s}}, \gamma_{\mathrm{m}}$ 分布を見ると, 接合筋の引張軸力と曲げモー メント負担率は異なっている。従って, 接合筋の引張によるせん断 摩擦が，接合筋のダウエル抵抗より大きく支配されていることが判 る。ここで，微小変形で最大耐力のせん断抵抗 $Q_{u}$ は接合筋のダウ エル抵抗 $Q_{d}$ を無視して, ジョイント部コンクリートのせん断抵抗 $Q$ $c$ と接合笳のせん断摩擦抵抗 $Q_{f}$ の和として次式のように与えられる。

$Q_{u}=Q_{C}+Q_{f}$

$Q_{C}=\min \left(Q_{C 1}, Q_{C 2}\right)$

$Q_{C l}=\min \left(Q_{S C}, Q_{C C}\right)$

ここで, シアキーのせん断抵抗 Qcl は, シアキーの直接せん断破 壊及び支圧破壊によって，既往の研究によって，以下の式によって 与えられる。

$$
\begin{aligned}
& \mathrm{Q}_{\mathrm{sc}}=0.09 \cdot \sigma_{\mathrm{Bp}} \cdot \mathrm{A}_{\mathrm{sc}} \cdot \mathrm{n}(\text { シアキーせん断破壊 })^{8)} \\
& \mathrm{Q}_{\mathrm{cc}}=\sigma_{B p} \cdot A_{s} \cdot n \quad(\text { シアキー支压破壊 })^{6)}
\end{aligned}
$$

ここで， $\sigma_{B p}$ はコンクリート圧縮強度(PCa 部又は接合部の圧縮強

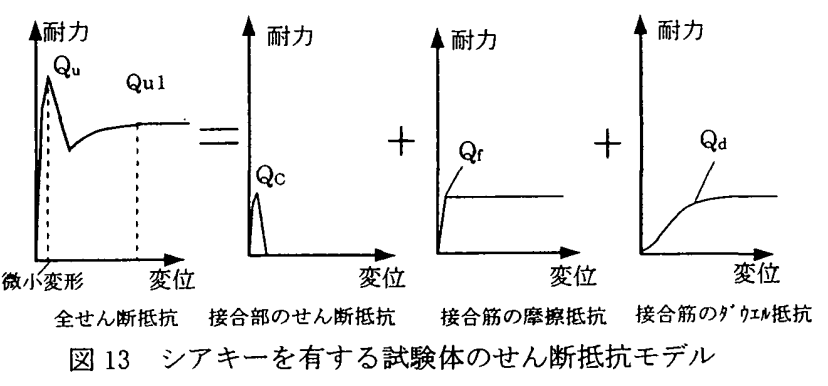

度の低い方の値)，ASC，Asはシアキーの水平投影面積及び鉛直投影 面積，nはシアキーの個数である。

\section{2 接合筋のせん断摩擦抵抗 $Q_{f}$}

接合筇のせん断摩摖抵抗 $Q_{f}$ に関して，図 14 に示すように，シア キ一内に接合筋を有する場合について，接合部コンクリート内部で， 接合筋の降伏合力 $N$ と斜めストラットに生じる圧縮合力及びせん 断摩擦力 $Q_{f}$ が釣り合いを保つ。軸心と $\phi$ の傾きをもつストラットに よる微小要素を考えると,ストラットの圧縮力による応力 $\sigma_{S}$ とせん 断力による応力 $\tau_{s}$ が作用する。

接合幅を有する場合，図 12 に示すように，接合幅が大きくになる につれて，接合筋が生じる軸力は漸減していることより，接合幅を 有する試験体の接合筋のせん断摩擦抵抗 $\mathrm{Q}_{\mathrm{f}}$ は，図 12 の近似曲線か ら得られた低減係数 $\gamma_{\mathrm{s}}$ を適用すると，次式のように与えられる。

$Q_{f}=\mu \cdot N=\mu \cdot \gamma_{s} \cdot N_{0}=\gamma_{s}\left(\mu \cdot 0.74 \cdot \Sigma a_{s} \cdot \sigma_{y}\right)=\gamma_{s} \cdot Q_{f 0}$

既往の研究 ${ }^{87,9)}$. によると，接合幅が 0 の場合に生じるせん断摩 擦抵抗 $\mathrm{Qf}_{0}\left(=\mu \mathrm{N}_{0}\right)$ は，修正 Mohr-Coulomb 理論から導かれた接合筋に よるせん断摩檫抵抗望月式 $\left.Q_{f 0}=0.54 \cdot \Sigma a_{s} \cdot \sigma_{y}{ }^{8}\right)$ が多くの実験から検 証された。ここで，本論文と照合すると，望月氏等が示した論文に よると軸力低减係数は，0.64 となっている。本論の実験結果に基づ く回帰式による軸力低减率は，0.74で望月らの 0.64 より高い值を 示しているが, 平均値 0.61 と比べるとほぼ一致することから,ここ で，望月式を採用すると，(7)式は次式のように変換される。

$$
Q_{f}=\gamma_{s} \cdot Q_{f_{0}}=e^{-0.0029 L_{j}} 0.54 \cdot \Sigma a_{s} \cdot \sigma_{y}
$$

ここで， $a_{s}$ は，接合筋の全断面積， $\sigma_{y}$ ，接合筋の降伏強度， $\mathrm{L}_{j}$ は, ジョイント接合幅 $(\mathrm{mm})$ 。

また, シアキー間に形成された压縮ストラット中の応力 $\sigma \mathrm{s}$ とせ L断応力 $\tau \mathrm{s}$ を接合面の垂直及び水平な応力 $\left(\sigma_{X}, \sigma_{r}, \tau_{\gamma r}\right)$ に変換 すると, 次式が成り立つ。

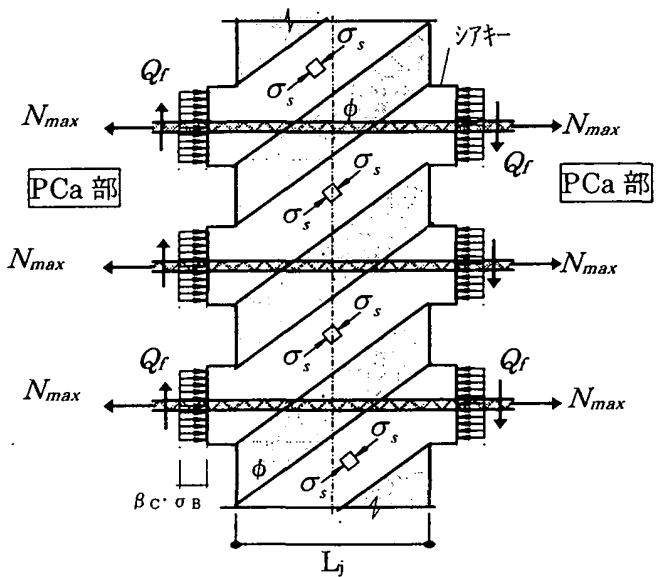

図 14 接合筋摩擦抵抗によるストラット機構 


$$
\sigma_{x}=\sigma_{s} \sin ^{2} \dot{\phi}-2 \tau_{s} \sin \phi \cos \phi
$$

$\sigma_{y}=\sigma_{s} \cos ^{2} \phi+2 \tau_{s} \sin \phi \cos \phi$

$\tau_{x y}=\sigma_{s} \sin \phi \cos \phi-\tau_{s}\left(\cos ^{2} \phi-\sin ^{2} \phi\right)$

ジョンイントコンクリート部に形成された圧縮ストラットの中に, $\tau \mathrm{s}$ を無視すると， (9)式から， $\sigma_{s}$ 及び $\tau_{x y}$ は, 次式のように与えら れる。

$$
\tau_{x y}=\sigma_{s} / \tan \phi
$$

ここに，せん断力がストラットにおいて一様に分布していると仮 定すると，シアキーに作用するせん断抵抗 $\mathrm{Q}_{\mathrm{f}}$ は， $\mathrm{Q}_{\mathrm{f}}=\tau_{\mathrm{xy}} \cdot \mathrm{n} \cdot \mathrm{bh}$ 及び $\sigma \mathrm{s}=\sigma \mathrm{x}=\beta \mathrm{C}^{\cdot} \sigma_{\mathrm{B}}$ の関係を用いると，(10)式から次のように表される。

$$
Q_{f}=\beta_{C} \cdot \sigma_{B} \cdot n \cdot b h / \tan \phi
$$

ここで, $\tan \phi=\mathrm{L}_{\mathrm{j}} \mathrm{h}$ (接合幅が小さい場合), または $\tan \phi=\mathrm{L}_{\mathrm{j}} /(2 \mathrm{~h}+\mathrm{H})$ (接合幅が大きい場合)， $\beta \mathrm{c}$ は，コンクリートの圧縮ブロック保数。 (11)式から接合幅 L また, 圧縮ストラットに作用する圧縮力は, シアキーの界面におい て, 水平応力度 $\sigma \mathrm{x}$ による合力に対応する接合筋の引張軸方向力 $\mathrm{N}$ と等しくなる。従って，て s 無視すると，(9)式と図 14 から次式を 導かれた。

$$
N=\sigma_{S} \cdot n \cdot b \cdot h \approx \beta_{C} \cdot \sigma_{B} \cdot n \cdot b h / \sin ^{2} \phi
$$

これより，接合幅の軸力，接合幅 $\mathrm{Lj}$ が大きくなると，堿少するこ とが認められる。また， $\tau \mathrm{xy}=\mathrm{Q}_{\mathrm{f}} /(\mathrm{nbh}) を(10)$ 式に代入すると，压縮 ストラット応力 $\sigma_{s}$ は次式のように与える。

$$
\begin{aligned}
\sigma_{s} & =Q_{f} \cdot \tan \phi /(n \cdot b \cdot h) \\
& =e^{-0.0029 L j} \cdot 0.54 \cdot \sum a_{s} \cdot \sigma_{y} \cdot \tan \phi /(n \cdot b \cdot h)
\end{aligned}
$$

ここで，bは試験体厚さ $(\mathrm{mm}), \mathrm{h}$ はシアキーの幅である $(\mathrm{mm}) 。$

\section{3 ジョイントコンクリートのせん断抵抗 $Q_{C 2}$}

ジョイントコンクリート接合部のせん断抵抗 $\left(Q_{C 2}\right)$ に関しては, 試験体のひび割れ性状を考慮し, 図 15 に示すように, 圧縮ストラッ トは, 接合幅が小さい時に, 1 組のシアキーの内部で形成されるが， 接合幅が大きい時には，2 組のシアキーにかけて形成される。そこ で，接合部のせん断抵抗 $\left(Q_{C_{2}}\right)$ は，次式に示した。

接合幅が小さい時 $(0<\mathrm{Lj} \leqq 60)$

$$
\begin{aligned}
& Q_{C_{2}}=A_{S} \cdot \sigma_{c} \cdot \tan \theta_{1} \cdot n \\
& \text { 接合幅が大きい時 } \quad(60<\mathrm{Lj} \geqq 200) \\
& Q_{C 2}=A_{S} \cdot \sigma_{c} \cdot \tan \theta_{2} \cdot(n-1)
\end{aligned}
$$

ここで， $\sigma c$ はシアキー間に形成されたストラットの圧縮灾力で

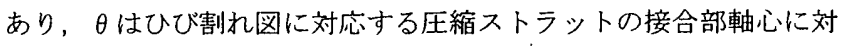
する傾斜角であり，接合幅が小さい場合， $\tan \theta_{1}=\mathrm{L}_{\mathrm{j}} / \mathrm{h}$ ，接合幅が 大きい場合， $\tan \theta_{2}=\mathrm{L}_{\mathrm{j}} /(2 \mathrm{~h}+\mathrm{H})$ 。接合幅を有する $\mathrm{PCa}$ 接合部がせ
接合幅が小さい場合

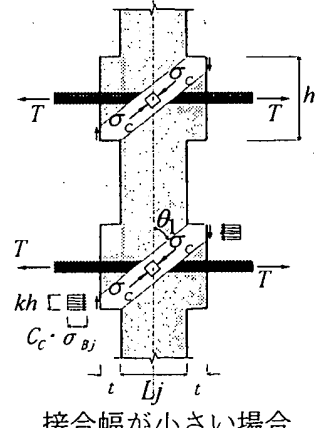

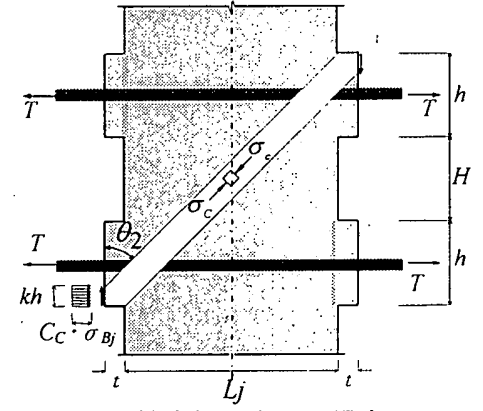

接合幅が大きい場合
図 15 圧縮ストラットによるせん断抵抗機構
ん断力を受けると，接合筋のせん断摩擦による圧縮ストラット機構 とジョイントコンクリートに形成された圧縮ストラットが同時に接 合部で混在する。そのため，図 14 及び図 15 に示すように，接合筋 のせん断摩擦による圧縮ストラット機構の中に生じている圧縮応力 $\sigma_{s}$ とシアキー間に形成された圧縮ストラット機構の中に生じる圧 縮応力 $\sigma_{\mathrm{c}}$ との間には, 両応力の傾きが異なることによる影響を無視 すると，下式が成り立つ。

$$
\sigma_{S}+\sigma_{C}=v \cdot \sigma_{B j}
$$

ここで， $\sigma_{\mathrm{Bj}}$ は接合部モルタルの圧縮強度。 $v$ は圧縮ストラット 内部のモルタル (コンクリート). 圧縮強度の軟化低减倸数。本来, 低減係数 vは鉄筋比及びひび割れに大きく影響されるが，ここでは 簡単にするために，これを無視して，コンクリートの圧縮強度のみ を考虑し, 有効係数 $\nu=0.7-\left(\sigma_{\mathrm{Bj}} / 200\right)$ 4)を採用した。(16)式を利 用すると，(14)及び(15) 式は次式のように書き換えられる。

接合幅が小さい時

$$
Q_{C 2}=A_{S} \cdot\left(\nu \sigma_{B j}-\sigma_{.}\right) \cdot \tan \theta_{1} \cdot n
$$

接合幅が大きい時

$$
Q_{C 2}=A_{S} \cdot\left(\nu \sigma_{B j}-\sigma_{s}\right) \cdot \tan \theta_{2} \cdot(n-l)
$$

式(3)〜(16)から，接合幅を有する $\mathrm{PCa}$ 接合部のせん断抵抗 $\mathrm{Q}_{\mathrm{u}}$ が 得られる。得られた実験値と提案式の比較を図 16 に示した。接合幅 を考虑した本提案式は, 接合幅 $0 \mathrm{~mm} の$ 結果を除いて, 平均値は 1.01 , 相関係数 $\gamma$ は 0.87 , 標準偏差 $\sigma$ は 0.167 が得られ, 実験結果とよ く対応しているものと考えられる。ただし，上述のせん断抵抗式は， 次の適用範囲の中で考えなければならない。

\section{$0 \leqq \sigma_{\mathrm{B}} \leqq 35 \mathrm{~N} / \mathrm{mm}^{2}, \quad 345 \mathrm{~N} / \mathrm{mm}^{2} \leqq \sigma \mathrm{y} \leqq 395 \mathrm{~N} / \mathrm{mm}^{2}$, \\ $10 \mathrm{~mm} \leqq \mathrm{~d}_{\mathrm{b}} \leqq 16 \mathrm{~mm}, \quad 0 \mathrm{~mm}<\mathrm{Lj} \leqq .200 \mathrm{~mm}$}

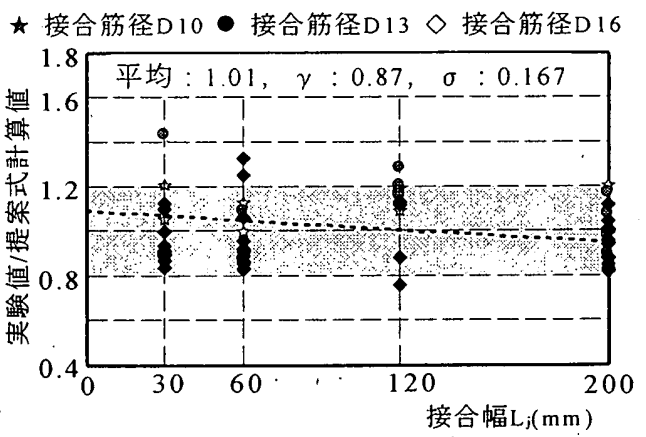

図 16 実験值/提案式值一接合幅との関係

5. まとめ

シアキーと接合幅を有する $\mathrm{PCa}$ 接合部におけるせん断実験を 行い, 以下の事柄が示唆される。

1 ·接合幅を有するPCa 接合部では, 接合幅の違いによって, せん 断耐力は著しく変動する。

2・接合幅により破壊性状が異なり，接合部に生じる斜めひび割れ によって最大耐力は与えられる。

3・最大耐カレベルに対して；接合筋のせん断摩擦抵抗はダウエル 抵抗より支配的である。接合幅が大きくなるにつれ，接合筋の せん断摩擦抵抗も漸隇する傾向を示す。

4・ジョイントコンクリートからなる接合部において圧縮ストラッ 卜機構を提案し，これより導かれた評価式は，実験結果をよく 表わしていると判断される。 
表4 試験体強度一覧表

\begin{tabular}{|c|c|c|c|c|c|c|c|c|c|c|c|c|c|c|c|}
\hline \multirow[b]{2}{*}{ No } & \multirow[b]{2}{*}{ 試験体 } & \multicolumn{2}{|c|}{ 最大耐力 } & \multirow[b]{2}{*}{$\begin{array}{c}Q_{\mathrm{f}} \\
(\mathrm{kN})\end{array}$} & \multirow[b]{2}{*}{$\begin{array}{c}\mathrm{Qc} \\
(\mathrm{kN})\end{array}$} & \multirow[b]{2}{*}{$\begin{array}{c}\mathrm{Qu} \\
(\mathrm{kN})\end{array}$} & \multirow{2}{*}{$\begin{array}{l}\text { 破壊 } \\
€-卜 1\end{array}$} & \multirow[b]{2}{*}{ NO } & \multirow[b]{2}{*}{ 試験体 } & \multicolumn{2}{|c|}{ 最大耐力 } & \multirow[b]{2}{*}{$\begin{array}{c}Q_{\mathrm{f}} \\
(\mathrm{kN})\end{array}$} & \multirow{2}{*}{$\begin{array}{c}\mathrm{Qc} \\
(\mathrm{kN})\end{array}$} & \multirow{2}{*}{$\begin{array}{c}\mathrm{Qu} \\
(\mathrm{kN})\end{array}$} & \multirow{2}{*}{$\begin{array}{l}\text { 破壊 } \\
\text { - }\end{array}$} \\
\hline & & $\begin{array}{l}\text { 耐力 } \\
(\mathrm{kN})\end{array}$ & $\begin{array}{l}\text { 変位 } \\
(\mathrm{mm})\end{array}$ & & & & & & & $\begin{array}{l}\text { 耐力 } \\
(\mathrm{kN})\end{array}$ & $\begin{array}{l}\text { 変位 } \\
(\mathrm{mm})\end{array}$ & & & & \\
\hline 13 & JPC00-10×2-C1-30 & 175.4 & $\overline{0.44}$ & 28.2 & 96.9 & 125.1 & $\overline{\mathrm{A}}$ & 834 & JPC200-16×2-A-30 & \begin{tabular}{ll|}
74.3 \\
\end{tabular} & 0.33 & 50.8 & 46.5 & 97.4 & $\bar{F}$ \\
\hline 2 & JPC00-13×2-C1-30 & 185.7 & 0.48 & 51.2 & 96.9 & 148.1 & $\mathrm{AD}$ & 35 & JPC200-16×2-B-30 & 81.7 & 0.12 & 50.8 & 34.9 & 85.7 & $\bar{F}$ \\
\hline 3 & $\mathrm{JPC} 00-16 \times 2-\mathrm{Cl}-30$ & 227.1 & 0.83 & 79.7 & 96.9 & 176.6 & $\mathrm{AD}$ & 36 & JPC200-16×2-E-30 & 90.6 & 0.24 & 50.8 & 53.1 & 104.0 & $\bar{F}$ \\
\hline 4 & $\mathrm{JPC} 00-16 \times 2-\mathrm{Cl}-40$ & 187.4 & 0.43 & 79.7 & 96.9 & 176.6 & $\overline{\mathrm{AB}}$ & 37 & $\mathrm{JPC} 30-16 \times 3-\mathrm{Cl}-30$ & 212.2 & 1.12 & 116.6 & 122.7 & 239.3 & FA \\
\hline 5 & $\mathrm{SPC} 30-10 \times 2-\mathrm{Cl}-30$ & 144.8 & 0.38 & 26.1 & 94.07 & 120.2 & $\overline{F A}$ & 38 & $\mathrm{JPC} 30-16 \times 3-\mathrm{Cl}-30$ & 217.2 & 0.33 & 116.6 & 122.7 & 239.3 & FA \\
\hline 6 & JPC $30-13 \times 2-\mathrm{Cl}-30$ & 199.6 & 0.51 & 47.5 & 89.94 & 137.4 & $\overline{\mathrm{FA}}$ & 39 & JPC60-16×3-C1-30 & 200.8 & 1.08 & 108.2 & 125.1 & 233.3 & FA \\
\hline 7 & JPC $30-16 \times 2-\mathrm{Cl}-30$ & 132.5 & 0.41 & 74.0 & 84.8 & 158.8 & FA & 40 & JPC60-16×3-C1-30 & 163.1 & 0.51 & 108.2 & 83.4 & 191.6 & $\mathrm{~F}$ \\
\hline 8 & JPC $60-10 \times 2-\mathrm{Cl} 1-30$ & 116.3 & 0.54 & 24.2 & 92.9 & 117.1 & $\overline{\mathrm{FA}}$ & 41 . & JPC $60-16 \times 3-C 2-30$ & 213.7 & 1.02 & 108.2 & 125.1 & 233.3 & FD \\
\hline 9 & JPC60-13×2-C1-30 & 144.4 & 0.78 & 44.0 & 89.06 & 133.1 & FA & 42 & JPC60-16×3-C3-30 & 235.4 & 1.01 & 108.2 & 114.6 & 222.8 & $\overline{F E}$ \\
\hline 10 & JPC60-16×2-C1-30 & 145.7 & 0.48 & 68.6 & 84.29 & 152.9 & FA & 43 & JPC200-16×3-C1-30 & 113.3 & 0.11 & 76.2 & 61.4 & 137.6 & $\mathrm{FA}$ \\
\hline 11 & $\mathrm{JPC} 120-10 \times 2-\mathrm{Cl}-30$ & 95.6 & 0.41 & 20.9 & 47.87 & 68.7 & $\mathrm{~F}$ & 44 & JPC200-16×3-Cl-30 & 123.1 & 0.10 & 76.2 & 75.6 & 151.8 & $\mathrm{~F}$ \\
\hline 12 & JPC120-13 $\times 2-C 1-30$ & 137.5 & 1.00 & 37.9 & 46.22 & 84.1 & $\bar{F}$ & 45 & JPC200-16×3-C2-30 & 133.0 & 0.14 & 76.2 & 75.6 & 151.8 & $\mathrm{~F}$ \\
\hline 13 & JPC120-16×2-C1-30 & 147.8 & 0.98 & 59.1 & 44.17 & 103.2 & $\bar{F}$ & 46 & JPC200-16×3-C $3-30$ & 151.2 & 0.98 & 76.2 & 75.6 & 151.8 & FA \\
\hline 14 & JPC200-10 $\times 2-\mathrm{Cl}-30$ & 78.4 & 0.48 & 17.1 & 48.24 & 65.3 & $\bar{F}$ & 47 & $\mathrm{JPC} 00-10 \times 2-\mathrm{F}-30$ & 155.2 & 1.30 & 35.1 & 148.0 & 183.1 & $\mathrm{AB}$ \\
\hline 15 & JPC200-13×2-Cl-30 & 83.4 & 0.4 & 31.0 & (46.89 & 77.9 & $\mathrm{FE}$ & 48 & $\mathrm{JPC} 00-13 \times 2-\mathrm{F}-30$ & 267.5 & 1.20 & 53.2 & 142.0 & 195.2 & $\mathrm{AB}$ \\
\hline 16 & JPC200-16 $\times 2-\mathrm{C} 1-30$ & 104.0 & 0.52 & 48.4 & 45.21 & 93.6 & FA & 49 & $\mathrm{JPC} 00-16 \times 2-\mathrm{F}-30$ & 352.2 & 0.47 & 86.7 & 142.0 & 228.7 & $\mathrm{AB}$ \\
\hline 17 & JPC200-16×2-Cl-40 & 97.0 & 0.23 & 48.4 & 45.21 & 93.6 & $\mathrm{~F}$ & 50 & JPC30-10×2-F-30 & 190.6 & 3.20 & 32.6 & 149.3 & 181.9 & $\mathrm{FE}$ \\
\hline 18 & JPC00-16×2-D-30 & 150.2 & 0.53 & 81.0 & 102.8 & 183.8 & $\mathrm{AB}$ & 51 & JPC30-13×2-F-30 & 168.0 & 0.08 & 49.4 & 140.6 & 189.9 & FD \\
\hline 19 & JPC00-16×2-D-40 & 149.2 & 0.47 & 81.0 & 102.8 & 183.8 & $\bar{A}$ & 52 & $\mathrm{JPC} 30-16 \times 2-\mathrm{F}-30$ & 191.6 & 0.78 & 80.4 & 125.2 & 205.7 & $\overline{F E}$ \\
\hline 20 & JPC30-16×2-D-30 & 132.5 & 0.41 & 75.2 & 58.17 & 133.3 & FD & 53 & JPC60-10×2-F-30 & 182.7 & 0.54 & 30.2 & 131.9 & 162.2 & FA \\
\hline 21 & JPC30-16×2-D-40 & 120.6 & 0.44 & 75.2 & 58.17 & 133.3 & FD & 54 & $\mathrm{JPC} 60-13 \times 2-\mathrm{F}-30$ & 149.7 & 1.04 & 45.8 & 126.9 & 172.7 & $\mathrm{FD}$ \\
\hline 22 & JPC60-16×2-D-40 & 116.2 & 0.52 & 69.7 & 58.83 & 128.5 & FA & 55 & JPC60-16×2-F-30 & 162.6 & 0.95 & 74.6 & 109.6 & 184.3 & $\mathrm{~F}$ \\
\hline 23 & JPC60-16×2-D-40 & 105.3 & 0.38 & 69.7 & 58.11 & 127.8 & $\overline{\mathrm{FA}}$ & 56 & $\mathrm{JPCl} 20-10 \times 2-\mathrm{F}-30$ & 115.3 & 0.49 & 26.0 & 80.0 & 106.0 & $\mathrm{FE}$ \\
\hline 24 & $\mathrm{JPCl} 20-16 \times 2-\mathrm{D}-30$ & 65.1 & 0.02 & 60.0 & 29.64 & 89.6 & FA & 57 & $\mathrm{JPC} 120-13 \times 2-\mathrm{F}-30$ & 130.2 & 0.10 & 39.4 & 72.2 & 111.6 & $\mathrm{FE}$ \\
\hline 25 & JPC120-16×2-D-40 & 78.5 & 0.26 & 60.0 & 29.64 & 89.6 & $\mathrm{FA}$ & 58 & JPC120-16×2-F-30 & 148.6 & 0.08 & 64.2 & 67.8 & 132.0 & $\mathrm{~F}$ \\
\hline 26 & JPC200-16×2-D-40 & 84.14 & 0.29 & 49.1 & 40.77 & 89.9 & $F$ & 59 & $\mathrm{JPC} 200-10 \times 2-\mathrm{F}-30$ & 86.2 & 0.24 & 21.3 & 66.9 & 88.2 & FD \\
\hline 27 & JPC200-16×2-D-40 & 84.14 & 0.93 & 49.1 & 40.77 & 89.9 & $F$ & 60 & $\mathrm{JPC} 200-13 \times 2-\mathrm{F}-30$ & 83.2 & 1.10 & 32.3 & 61.2 & 93.5 & $F$ \\
\hline 28 & JPC30-16×2-A-30 & 146.7 & 0.49 & 77.7 & 55.4 & 133.1 & FD & 61 & JPC200-16×2-F-30 & 110.3 & 0.57 & 52.6 & 57.6 & 110.2 & $\bar{F}$ \\
\hline 29 & JPC30-16×2-B-30 & 182.2 & 0.51 & 77.7 & 88.72 & 166.5 & FD & 62 & $\mathrm{JPC1} 20-13 \times 3-G-30$ & 141.2 & 0.54 & 59.1 & 63.6 & 122.7 & $\mathrm{FE}$ \\
\hline 30 & JPC30-16×2-E-30 & 153.2 & 0.81 & 77.7 & 59.15 & 136.9 & FD & 63 & $J P C 200-13 \times 3-G-30$ & 110.8 & 0.08 & 48.4 & 65.9 & 114.3 & $\mathrm{~F}$ \\
\hline 31 & $\sqrt{3 P C 60-16 \times 2-A-30}$ & 174.4 & 2.03 & 72.1 & 55.4 & 127.5 & FE & 64 & JPC1 20-13×4-G-30 & 208.9 & 1.80 & 78.9 & 102.6 & 181.4 & $\mathrm{FE}$ \\
\hline 32 & JPC60-16×2-B-30 & 134.0 & 1.46 & 72.1 & 89.81 & 161.9 & FA & 65 & JPC200-13×4-G-30 & 198.6 & 1.70 & 64.6 & 106.1 & 170.6 & FD \\
\hline 33 & JPC60-16×2-E-30 & 150.2 & 1.62 & 72.1 & 29.94 & 102.1 & $\mathrm{FE}$ & 66 & JPC120-13×5-G-30 & 270.4 & 0.80 & 98.6 & 127.1 & 225.7 & $\mathrm{~F}$ \\
\hline
\end{tabular}

\section{参考文献}

1)日本建築学会編：「鉄筋コンクリート構造計算基淮·同解説」 1999

2) 日本建築学会編：「壁式プレキャスト構造鉄筋コンクリート造設計基淮·同解

説了, 1982

3）日本建築学会編 : 「プレキャスト鉄筋コンクリート構造の設計と施エ」, 1986 4) 日本建築学会 : 鉄筋コンクリート造建物の勒性保証型耐震設計指針·同解説, 1997

5)斉㗍, 植谷栄次, 水上明, 謝爽: シアキーがなく接合幅を持つ PCa 構造接合部 のせん断挙動と耐力に関する研究, 日本建築学会構造系論文集, 第 560 号, pp. $147 \sim 154,2002.10$

6) 日本建案学会編「現場打ち同等型プレキャスト鉄筋コンクリート構造設計指 針·同解説 (2002)」, pp. 67 69, 2002

7) 黑正清治:プレカストコンクリート構造接合部に関する研究, 日本建築学会 論文集, No. 89, pp. 141，1963.9,

8)日本建築学会編：「壁プレキャスト構造の鉿直接合部の挙動と設計法」, pp. 103, 1989

9) Shuang XIE., Eiji MAKITANI., Syouhei OGAWA : The Dowel Action of Steel Bars in the Joint Connection of Precast Reinforced Concrete, Proceeding of the Japan Concrete Institute., Vol. 6., No. 2., pp. 835 840, 1994

10) 小野寺知子, 植谷栄次, 水上明, 謝㷋：「シアキーを有する $P C a$ 構造接合部に おけるせん断伝達に関する研究（その 1，その2)」 日本建築学会大会賆演梗 概集 (九州)，pp. 759〜 762, 1998.9

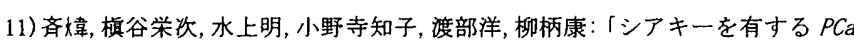
構造接合部におけるせん断伝達に関する研究(その3，その 4，その5.)」 日 本建築学会大会講演梗概集 (中国)，pp. 643〜 648，1999.9
12)植谷榮次, 小川祥平, 謝爽!「接合幅を有するプレキャスト部材接合部のダウ エル筋のせん断伝達(その1〜2)」'日本建築学会大会学術講演梗概集 (北陸)， pp. $761 \sim 764,1994.9$

13）吉野次彦・槙谷栄次·松崎育弘·石橋一彦・永坂具也：「プレキャスト部材接合 面の性能に関する研究（その1，その2，その3）既往の耐力評価式と滑り変位 の関倸について一接合幅を有する場合」，日本建築学会大会講演梗概集 (北海 道), 1995.8

14）大淵英夫，中野克彦，松崎育弘他：「ずれ変形を考慮したプレキャスト部材接 合面におけるせん断伝達に関する研究」 日本建築学会構造系論文報告集 491 号, pp. 97 104, 1997. 6

15)望月重, 植谷榮次, 永坂具也: [壁式プレキャスト鉄箉コンクリート造鉛直接 合部のせん断耐力」 日本建築学会構造系論文報告集, 第 424 号, pp. 11 p22, 1991.6

16)文嘲, 槙谷栄次, 水上明:シアキーと接合幅を有する P C a 構造接合部のせ ん断伝達に関する研究，コンクリート工学年次論文集，Vol. 24, No. 2, pp. 697 $\sim 702,2002.6$

17) 斉媁, 槙谷栄次, 伊藤募則: シアキーと接合幅を有する $\mathrm{PC} \mathrm{a}$ 構造接合部の せん断伝達に関する研究，コンクリート工学年次論文集，Vol. 25，No. 2, 697 $\sim 702,2003.7$

18）松崎育弘, 福山淳, 木村博：壁式プレキャスト鉄筋コンクリート構造の鉛直 接合部に関する実験研究，日本建築学会大会学術講演梗概集(九州) pp. 211 $\sim 212, \quad 1989.10$

(2003年 7 月 7 日原稿受理, 2004 年 1 月 7 日採用決定 